\title{
Elemental carbon in snow at Changbai Mountain, northeastern China: concentrations, scavenging ratios, and dry deposition velocities
}

\author{
Z. W. Wang ${ }^{1}$, J. C. Gallet ${ }^{2}$, C. A. Pedersen ${ }^{2}$, X. S. Zhang ${ }^{1}$, J. Ström ${ }^{3}$, and Z. J. Ci ${ }^{1}$ \\ ${ }^{1}$ Research Center for Eco-Environmental Sciences, Chinese Academy of Sciences, P.O. Box 2871, Beijing 100085, China \\ ${ }^{2}$ Norwegian Polar Institute, Troms $\emptyset$, Norway \\ ${ }^{3}$ Department of Applied Environmental Science, Stockholm University, Stockholm, Sweden
}

Correspondence to: Z. W. Wang (wangzhw@ @rcees.ac.cn) and X. S. Zhang (zhangxsh@rcees.ac.cn)

Received: 5 May 2013 - Published in Atmos. Chem. Phys. Discuss.: 30 May 2013

Revised: 5 November 2013 - Accepted: 6 December 2013 - Published: 22 January 2014

\begin{abstract}
Light-absorbing aerosol - particularly elemental carbon (EC) - while mixed with snow and ice is an important climate driver from the enhanced absorption of solar radiation. Currently, considerable efforts are being made to estimate its radiative forcing on a global scale, but several uncertainties remain, particularly those regarding its deposition processes. In this study, concurrent measurements of EC in air and snow are performed for three years (20092012) at Changbai station, northeastern China. The scavenging ratio and the wet- and dry-deposition fluxes of EC over the snow surface are estimated. The mean EC concentration in the surface snow is $1000 \pm 1500 \mathrm{ng} \mathrm{g}^{-1}$, ranging from 7 to $7640 \mathrm{ng} \mathrm{g}^{-1}$. The mean value of the scavenging ratio of EC by snow is $140 \pm 100$, with a median value of 150, which is smaller than that reported in Arctic areas. A non-rimed snow process is a significant factor in interpreting differences with Arctic areas. Wet-deposition fluxes of EC are estimated to be $0.47 \pm 0.37 \mu \mathrm{g} \mathrm{cm}^{-2}$ month $^{-1}$ on average over the three snow seasons studied. Dry deposition is more than five times higher, with an average of $2.65 \pm 1.93 \mu \mathrm{g} \mathrm{cm}^{-2} \mathrm{month}^{-1}$; however, only winter period estimation is possible (December-February). During winter in Changbai, $87 \%$ of EC in snow is estimated to be due to dry deposition, with a mean dry deposition velocity of $6.44 \times 10^{-3} \mathrm{~m} \mathrm{~s}^{-1}$ and median of $8.14 \times 10^{-3} \mathrm{~m} \mathrm{~s}^{-1}$. Finally, the calculation of the radiative effect shows that $500 \mathrm{ng} \mathrm{g}^{-1}$ of dry-deposited EC to a snow surface absorbs three times more incoming solar energy than the same mass mixed in the snow through wet deposition. Deposition pro-
\end{abstract}

cesses of an EC-containing snow surface are, therefore, crucial to estimate its radiative forcing better, particularly in northeastern China, where local emission strongly influences the level and gradient of EC in the snowpack, and snowcovered areas are cold and dry due to the atmospheric general circulation. Furthermore, this study builds on the knowledge to characterize the conditions in the snow-laden Chinese rural areas better as well as to constrain transport of EC to the Arctic better.

\section{Introduction}

Elemental carbon (EC) is emitted from incomplete combustion of coal, fossil fuel, and biomass burning (Novakov et al., 2003; Jacobson, 2004). EC warms up the atmosphere by absorbing solar radiation while being suspended as in air, as well as by reducing the surface albedo while mixed with snow and ice. Both in air and on snow or ice, EC exerts a net positive forcing on the climate. EC particles may also influence cloud properties by acting as a nucleus for hydrometeors. This so-called indirect climate effect, via influencing cloud microphysical properties, is poorly understood. For a thorough discussion on this topic, we refer to Bond et al. (2013). Several studies have highlighted that EC (through positive feedback mechanisms) is the second most important climate warming driver after $\mathrm{CO}_{2}$ and could be in some regions comparable to greenhouse gas forcing (Bachmann, 2009; Shindell and Faluvegi, 2009). 
The current model-estimated EC forcing is between 0.03 and $0.13 \mathrm{~W} \mathrm{~m}^{-2}$ over snow surfaces (Koch et al., 2010; Flanner et al., 2007, 2009) with a stronger effect in the Arctic during spring, reaching $1.5 \mathrm{~W} \mathrm{~m}^{-2}$ (Flanner et al., 2007). The snow albedo feedback directly affects the climate by increasing the amount of energy absorbed, therefore increasing the snowpack's melting rate (Hansen and Nazarenko, 2004; Jacobson, 2004; Flanner et al., 2007). Although the EC-Arcticmean snow forcing is considerably greater than the global mean, radiative forcing exerted by EC outside the Arctic may have a significant influence on the global atmospheric dynamical changes and therefore the potential feedback on the Arctic climate (AMAP, 2011). Recently, EC has also been shown as a key element in the Himalayan glacier melting (Menon et al., 2010; Ming et al., 2012; Yasunari et al., 2013). Therefore, the climatic effects of EC outside of the polar region have received considerable attention.

In China, the snow cover is mainly extended towards the northeast, the northwest, and the Tibetan Plateau. Global climate modeling suggests that the Tibetan Plateau has the highest degree of soot-related snow forcing in the world, followed by the areas in northern and eastern China where very high regional emissions of soot and significant snowfall intersect (Flanner et al., 2007). Soot and black carbon (BC) are often used interchangeably in the literature. $\mathrm{EC}$ is a subset of $\mathrm{BC}$, and the use of $\mathrm{EC}$ and $\mathrm{BC}$ is typically defined by the analytical method used (Petzold et al., 2013). Huang et al. (2011) collected surface snow in January-February 2010, on a road trip of 40 sites in the north of China and reported EC concentrations from 40 to $1600 \mathrm{ng} \mathrm{g}^{-1}$, with a median of $500 \mathrm{ng} \mathrm{g}^{-1}$. Over the Tibetan Plateau, EC concentrations in the glacier snow (Ming et al., 2008) and ice core (Xu et al., 2009; Ming et al., 2012) were investigated, and the results indicated that EC deposited on the Tibetan glacier is a significant contributing factor to the glacier retreat. One of the key challenges in determining the effect of EC on snow surfaces is to quantify the rate at which EC is washed out from the atmosphere and deposited over snow surfaces (Cadle et al., 1988). So far, only a few studies have determined the washout ratio (e.g., Noone and Clarke, 1988; Cerqueira et al., 2010; Hegg et al., 2011). The reported values of the washout ratio present large variability, and yet are very important for obtaining results from climate models (Flanner et al., 2007; Hansen and Nazarenko, 2004). To add to the information on EC concentrations in snow over China, we performed sampling of EC in air and snow over three snow seasons (2009-2012); this was also necessary for deriving the washout ratios and drydeposition fluxes of EC around the Changbai station, northeastern China.

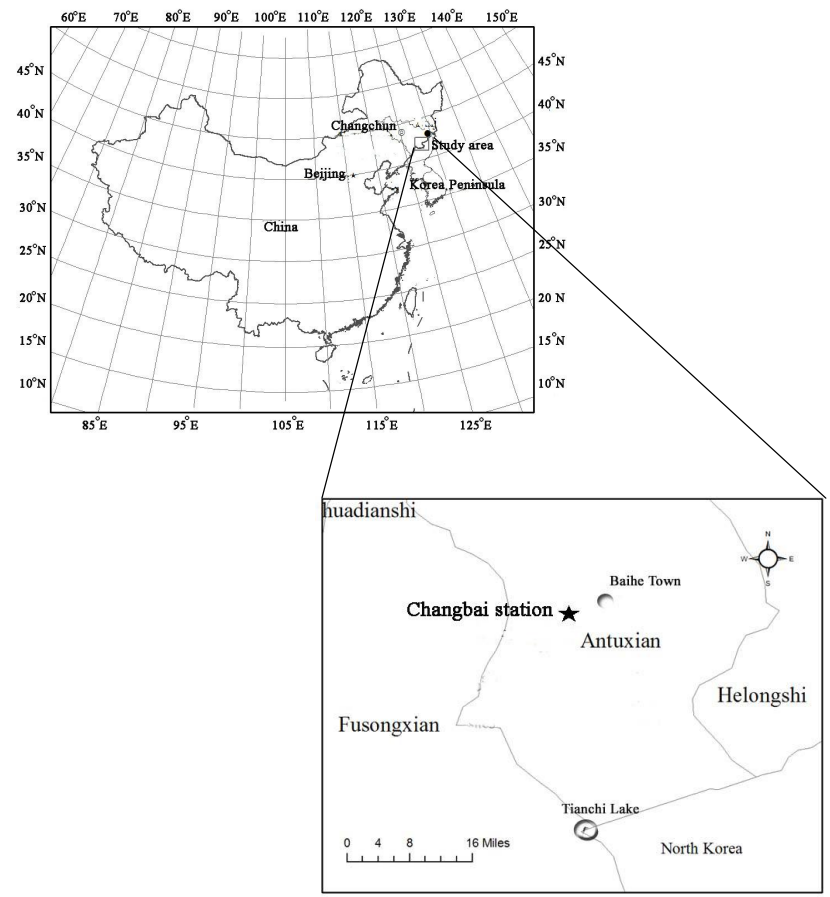

Fig. 1. Location of Changbai station in northeastern China.

\section{Methods}

\subsection{Site description, snow, and air sampling for EC content}

The Changbai Mountain stretches along the boundary between China and North Korea. The regional topography is characterized by forests and mountains with elevation from 410 to $2740 \mathrm{~m}$ a.s.l., decreasing gradually from the southeast to the northwest. It has a temperate continental monsoon climate with long cold winters and short temperate summers. The area is covered with snow for approximately 4-5 months from late fall to early mid-spring. The annual average temperature is $2.1^{\circ} \mathrm{C}$, and January is the coldest month, with an average temperature of $-20^{\circ} \mathrm{C}$. The Changbai Mountain is a national nature reserve with no large industrial facilities nearby. Our observation site is located at the Open Research Station of Changbai Mountain Forest Ecosystems, Chinese Academy of Sciences $\left(42^{\circ} 24^{\prime} \mathrm{N}\right.$, $128^{\circ} 28^{\prime}$ E; $738 \mathrm{~m}$ a.s.1.; Fig. 1), approximately $5 \mathrm{~km}$ away from the nearest town, Baihe, which has a population of about 49000 . The main sources of energy in the town are coal and biofuel combustion.

We performed snow sampling, typically once per week, during our three winter seasons (2009-2012). The snow samples consisted of the top $5 \mathrm{~cm}$ of the snowpack, collected in plastic bags by using shovels and gloves, transported to the laboratory, transferred into glass jars, and melted immediately in a microwave oven. The melted water was filtered through a quartz microfiber filter (Munktell, 420208, 
T293), and then dried and analyzed for EC content by using a thermo-optical method, which is detailed below. To estimate the impact of potential local sources of the city nearby, snow samples were collected on two occasions around the Changbai station within an approximate radial distance of $50 \mathrm{~km}$ in 2010 and 2012. Samples were also collected the same day at the station for comparison. Finally, approximately $50 \mathrm{~mL}$ of the melted water was filtered through a PTFE (polytetrafluoroethylene) filter (pore size: $0.45 \mu \mathrm{m}$ ) and stored in a refrigerator to determine the ion components of the snow. The atmospheric EC content was determined using a particle soot absorption photometer (PSAP), described below.

\subsection{Instrumentation and sample analysis}

A custom-built PSAP was developed by the Department of Applied Environmental Science, Stockholm University (hereinafter PSAP-ITM), and used for determining the level of carbon particle absorption in the atmosphere, often referred to as BC or EC. In the following text, the use of EC or BC refers to the same entity. PSAP-ITM measures the absorption of particles loaded on a filter substrate at a wavelength of $525 \mathrm{~nm}$. The measured absorption is then converted into concentration using the mass absorption cross section of $\mathrm{BC}\left(\mathrm{MAC}_{\mathrm{BC}}\right) . \mathrm{MAC}_{\mathrm{BC}}$ is found in the literature to vary from 4 to $20 \mathrm{~m}^{2} \mathrm{~g}^{-1}$ (Bond and Bergstrom, 2006). To obtain a good estimation of this variable at our site, we compared the measured atmospheric absorption of $\mathrm{BC}$ by using PSAP-ITM with the EC values determined using the thermooptical method during the first winter season 2009, following the study of Krecl et al. (2007). A total of 25 samples were used, each representing a $12 \mathrm{~h}$ sampling time. Results showed that the best fit between the absorption measured by PSAP-ITM and the EC concentration determined using the thermo-optical method was obtained with an $\mathrm{MAC}_{\mathrm{BC}}$ value of $8.68 \mathrm{~m}^{2} \mathrm{~g}^{-1}\left(R^{2}=0.96, n=25\right)$. This value is close to that recommended by Bond and Bergstrom (2006) $\left(7.5 \pm 1.2 \mathrm{~m}^{2} \mathrm{~g}^{-1}\right)$, and hence we will use our derived value in our study.

The sample inlet of our instrument was located $3 \mathrm{~m}$ above ground level. Aerosol particles were collected on a $3 \mathrm{~mm}-$ diameter sampling spot on E70-2075W filters (glass fibers with a cellulose baking, Pall Corporation, USA). The air flow was dynamic and adjusted to the ambient $\mathrm{BC}$ concentration, which gave typical values of $50 \mathrm{~mL} \mathrm{~min}^{-1}$. The uncertainty of such a method often depends on the determination of the $\mathrm{MAC}_{\mathrm{BC}}$ value for a specific site and the sampling of a light absorber other than $\mathrm{BC}$. The $\mathrm{MAC}_{\mathrm{BC}}$ value was determined for our site, and the effect of other aerosols was corrected for absorption and scattering artifacts, as detailed in Bond et al. (1999). Moreover, the BC concentration was within the range of 1000 to $2000 \mathrm{ng} \mathrm{m}^{-3}$ at the Changbai station, which is higher than most of the other background values at other sites. Thus, BC is probably the main absorber at the wavelength used by our instrument $(525 \mathrm{~nm})$. Second, re- suspension of dust in the atmosphere was most likely very small since measurements were conducted in winter, with snow on the ground and low wind. We estimated the accuracy of our instrument to be $10 \%$. The very high correlation between the $\mathrm{BC}$ and $\mathrm{EC}$ measurements when deriving the $\mathrm{MAC}_{\mathrm{BC}}$ supports this.

To determine EC in the snow surface, we used a Desert Research Institute (DRI) Model 2001A Thermal/Optical Carbon Analyzer (Atmoslytic Inc., Calabasas, CA, USA). This instrument determines the total carbon (TC) content loaded on a filter. TC represents the sum of organic carbon (OC) and EC: $\mathrm{TC}=\mathrm{OC}+\mathrm{EC}$. A $0.5 \mathrm{~cm}^{2}$ circular punch from the filter used for filtering the snow was analyzed for eight carbon fractions by using the IMPROVE_A protocol (Interagency Monitoring of Protected Visual Environments) (Chow et al., 2007). In summary, this protocol used temperature increments under different atmospheres to volatilize the carbon content deposited on the filter. Four fractions for the OC content were determined under a non-oxidant atmosphere (pure helium) under four temperature increments $(140,280,480$, and $580^{\circ} \mathrm{C}$ ), and three EC fractions were determined under an oxidant atmosphere (98\% helium and $2 \%$ oxygen) at three temperature levels $\left(580,740\right.$, and $\left.840^{\circ} \mathrm{C}\right)$. The four $\mathrm{OC}$ fractions were added to determine the $\mathrm{OC}$ content, and the same procedure was followed for calculating the EC content. During this protocol, OC can evolve as pyrolysis carbon, implying that the molecules are not volatilized but deteriorated. This issue was taken into account and corrected for by monitoring the light reflectance during the procedure. The volatilized carbon material was oxidized to $\mathrm{CO}_{2}$, later reduced to $\mathrm{CH}_{4}$, and quantified using a flame ion detector. The largest uncertainty in using such methods is the determination of the pyrolysis carbon; however, no perfect protocol exists because it depends on the type and concentration of the sampled aerosols, as detailed in Cavalli et al. (2010). In the DRI standard operating procedure, the precision of the $\mathrm{OC} / \mathrm{EC}$ split is $5 \%$ to $10 \%$, and is mostly influenced by the filter loading and source type. Another uncertainty is the "undercatch" of EC on the filter surface. This process in a recent study has been estimated to be $20 \%$ or $30 \%$ uncertain and even more for specific sites (S. Forsström, personal communication, 2012). Such a process might also be applicable to our samples, but probably in a much smaller amount, because the particles sampled here are larger compared to those sampled in the Arctic, since the source is closer. Second, the amount of EC is so high that even if some small particles are not caught, it represents a considerably smaller mass ratio to the total content. Overall, we estimated the uncertainty of the method to be $30 \%$, taking into account the thermooptical method and the possibility of undercatch during the filtering process. Finally, we filtered part of the melted water by using a PTFE filter. The filtered samples were stored in a refrigerator and later used for chemical analysis. Concentrations of anions and cations were determined using an ion chromatograph model DX-120, AS14, $25 \mu \mathrm{L}$ loop. 


\subsection{Meteorological data}

Meteorological data were provided by the local weather station at the Open Research Station of the Changbai Mountain Forest Ecosystems, Chinese Academy of Sciences. Air temperature, precipitation, atmospheric pressure, relative humidity, and wind speed were recorded using Vaisala Milos 520 weather station, with $1 \mathrm{~h}$ observation intervals. The air temperature near the snow surface $(2 \mathrm{~cm}$ above the snow surface) and that near the snow-soil interface were measured at 08:00, 14:00, and 20:00 local time every day during the snow seasons. The snow depth was recorded manually using stick measurements. A $20 \mathrm{~cm}$-diameter evaporation pan was used for manually determining sublimation from the snow surface. The pan evaporation technique is one of the simplest, most inexpensive, and most widely used methods of estimating evaporative losses, and successfully measures the sublimation of a seasonal snowpack (Hood et al., 1999; Box and Steffen, 2001; Zhang et al., 2004).

\section{Results and discussion}

\subsection{EC concentrations in snow at Changbai station}

Table 1 shows the results and descriptive statistics from the three snow seasons. The EC concentration ranges from 7 to $7640 \mathrm{ng} \mathrm{g}^{-1}$, with a mean value of $1000 \pm 1500 \mathrm{ng} \mathrm{g}^{-1}$. These concentrations are considerably higher than the values measured in the Himalayas and in western China, which were typically lower than $100 \mathrm{ng} \mathrm{g}^{-1}$ (Ming et al., 2008; Xu et al., 2009), and two orders of magnitude higher than those reported by Forsström et al. (2009) and Doherty et al. (2010) for Arctic areas. Huang et al. (2011) reported values ranging from 40 to $1600 \mathrm{ng} \mathrm{g}^{-1}$ in northeastern China, and Wang et al. (2013) measured a single value of $1700 \mathrm{ng} \mathrm{g}^{-1}$ in the same area as that considered in our study.

The mean and median EC values in snow are higher for the last snow season (2011-2012) than for the previous snow seasons despite the fact that the average atmospheric BC values are not the highest during that season. Atmospheric $\mathrm{BC}$ concentrations were $2.43,1.84$, and $2.08 \mu \mathrm{g} \mathrm{m}^{-3}$, respectively, and average precipitation values were 160, 46, and $107 \mathrm{~mm}$ of water equivalent for the snow seasons of 2009-2010, 2010-2011, and 2011-2012, respectively. Furthermore, the mean air temperatures between January and February were $-14.1,-14.3$, and $-16.5^{\circ} \mathrm{C}$, respectively, for 2010, 2011, and 2012. Even though January and February 2012 are slightly colder on average, moderate changes in atmospheric BC are found in this 2-month period, with values of $2.74,2.19$, and $2.44 \mu \mathrm{g} \mathrm{m}^{-3}$, respectively, for JanuaryFebruary 2010, 2011, and 2012. Thus, a comparison with other snow seasons shows that a higher load of BC in the snow surface appeared in the snow season of 2011-2012, with moderate $\mathrm{BC}$ concentration in air and precipitation in

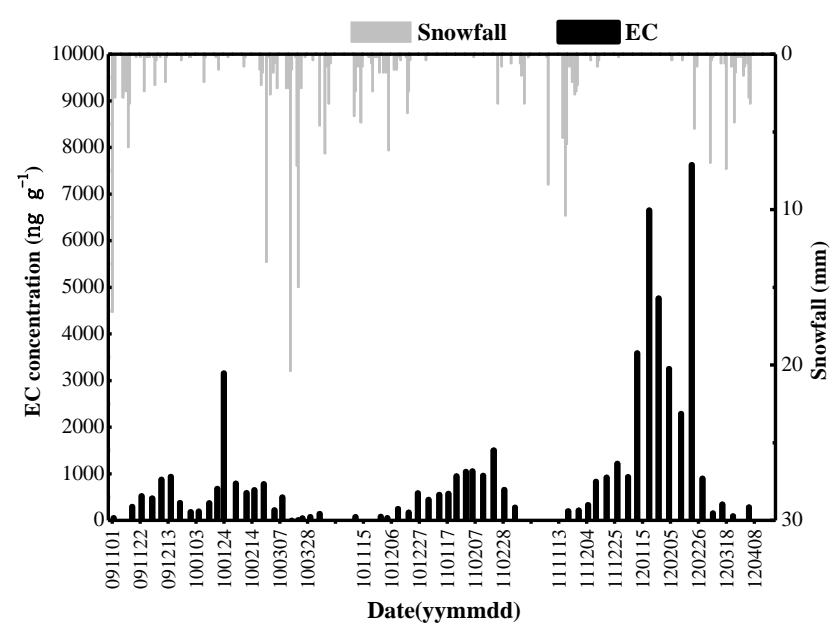

Fig. 2. EC concentrations in surface snow (ng g ${ }^{-1}$, weekly sampling) and daily snowfall in millimeter in water equivalent for winter season 2009-2011.

a slightly colder winter. Hence, the higher concentration in the snow is not simply explained by higher concentrations in the atmosphere. This would point toward a significant contribution from the dry deposition of EC in conjunction with extended period with low precipitation amounts (Fig. 2).

As presented in Table 1, snow samples are divided into "aged" and "fresh", depending on the time between the snowfall and sampling. The sample is classified as "fresh" if it was taken less than $12 \mathrm{~h}$ after a precipitation event, and as "aged" otherwise. The average EC value of fresh snow is $220 \pm 170 \mathrm{ng} \mathrm{g}^{-1}$, which is approximately one-seventh of that of aged snow (i.e., $1400 \pm 1700 \mathrm{ng} \mathrm{g}^{-1}$; Table 1). For example, in 2011, EC concentration in the surface snow significantly increased from 450 to $1070 \mathrm{ng} \mathrm{g}^{-1}$ from 3 January to 5 February, a period with no snowfall. A slight decrease was observed on 13 February $\left(970 \mathrm{ng} \mathrm{g}^{-1}\right)$ after $3 \mathrm{~cm}$ of fresh snow, reaching the highest value $\left(1510 \mathrm{ng} \mathrm{g}^{-1}\right)$ on 21 February (Fig. 2). Likewise, during the first 20 days of JanuaryFebruary 2012, EC increased from $940 \mathrm{ng} \mathrm{g}^{-1}$ (4 January) to $6660 \mathrm{ng} \mathrm{g}^{-1}$ (24 January), and decreased to $2300 \mathrm{ng} \mathrm{g}^{-1}$ after some snow events (13 February). Throughout these periods, the temperature was below freezing, and hence melting was unlikely; however, sublimation could have contributed to the enhancement of surface concentrations. In contrast, measurements of the evaporation rates showed small values. On average, the evaporation rates were 0.1 to $0.13 \mathrm{~mm} \mathrm{day}^{-1}$ in January 2011 and 2012, respectively (Fig. 3). If all that water evaporated came from the top $5 \mathrm{~cm}$ of snow, assuming a snow density of $0.25 \mathrm{~g} \mathrm{~cm}^{-3}$, this would cause an increase in concentration of only a few percent over a two-week period. 
Table 1. Summary of statistical EC concentrations $\left(\mathrm{ng} \mathrm{g}^{-1}\right)$ in snow at Changbai station.

\begin{tabular}{lrrrrrrrrrr}
\hline $\begin{array}{l}\text { Sampling } \\
\text { period }\end{array}$ & $\begin{array}{r}\text { Number } \\
N\end{array}$ & $\begin{array}{r}\text { Snowfall } \\
\mathrm{mm}^{*}\end{array}$ & $\begin{array}{r}\text { Snow depth } \\
\mathrm{cm}\end{array}$ & $\begin{array}{r}\text { EC } \\
\text { Min }\end{array}$ & $\begin{array}{r}\text { EC } \\
25 \%\end{array}$ & $\begin{array}{r}\text { EC } \\
\text { Median }\end{array}$ & $\begin{array}{r}\text { EC } \\
75 \%\end{array}$ & $\begin{array}{r}\text { EC } \\
\text { Max }\end{array}$ & $\begin{array}{r}\text { EC } \\
\text { Mean }\end{array}$ & $\begin{array}{r}\text { EC } \\
\text { Std. }\end{array}$ \\
\hline 9 Nov-10 Apr & 23 & 160 & $19.3 \pm 8.8$ & 7 & 170 & 390 & 670 & 3160 & 530 & 640 \\
10 Nov-11 Mar & 16 & 46 & $14.6 \pm 4.6$ & 60 & 240 & 570 & 960 & 1510 & 590 & 430 \\
11 Nov-12 Apr & 18 & 107 & $9.4 \pm 2.8$ & 100 & 300 & 920 & 3020 & 7640 & 1900 & 2300 \\
2009-2012 & 57 & 104 & $17.2 \pm 7.7$ & 7 & 210 & 530 & 940 & 7640 & 1000 & 1500 \\
Fresh snow & 19 & & & 7 & 80 & 170 & 240 & 790 & 220 & 170 \\
Aged snow & 38 & & & 80 & 530 & 840 & 1070 & 7640 & 1400 & 1700 \\
\hline
\end{tabular}

*Millimeter (mm) in snow water equivalent.

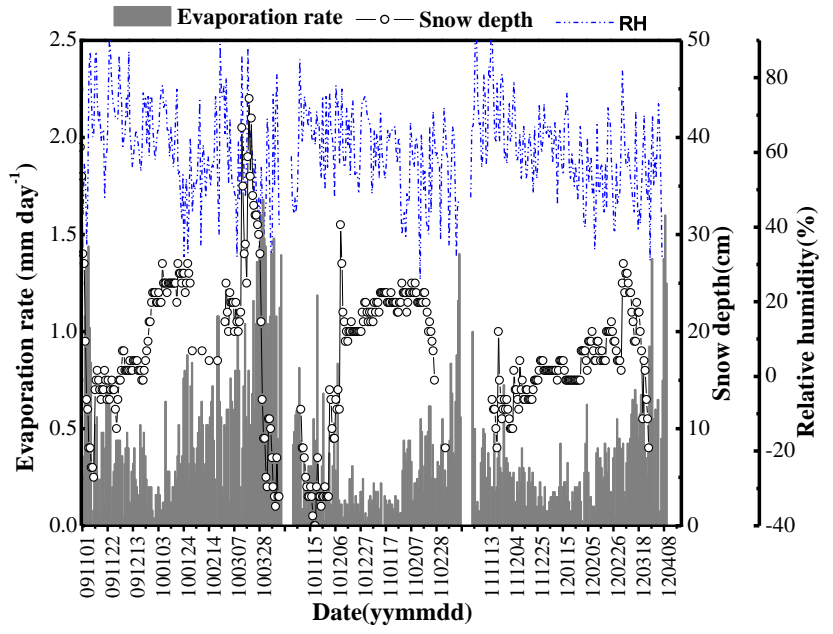

Fig. 3. Daily means of evaporation rate, snow depth, and relative humidity in winter season 2009-2010, 2010-2011, and 2011-2012.

\subsection{EC concentrations around Changbai Mountain}

As the emission from the potential local sources of the nearby city might impact our sample, two surveys of EC in the surface snow around the Changbai Mountain were conducted in 2010 and 2012 (Fig. 4). The same sampling protocol as that detailed in Sect. 2.1 was used, and an extra sample was taken at the station for comparison. During the first investigation on 22 January 2010, EC around Changbai ranged between 260 and $310 \mathrm{ng} \mathrm{g}^{-1}$, except for one higher value $\left(620 \mathrm{ng} \mathrm{g}^{-1}\right)$, and showed no obvious horizontal gradient. More sites were visited during the second investigation, and $\mathrm{EC}$ in the surface snow was found to be approximately five times higher in 2012 than in 2010. During the first survey, two snow events occurred, $0.2 \mathrm{~mm}$ on 18 January and $1 \mathrm{~mm}$ on the night of 20 January, just before our survey; therefore, the EC values were more representative of fresh snow than of aged snow. Before the second survey, more than 14 days had elapsed since the last observed precipitation.

In both surveys, EC around Changbai was significantly lower than the same-day concentration and the monthly mean concentration from the weekly snow sampling at the station.

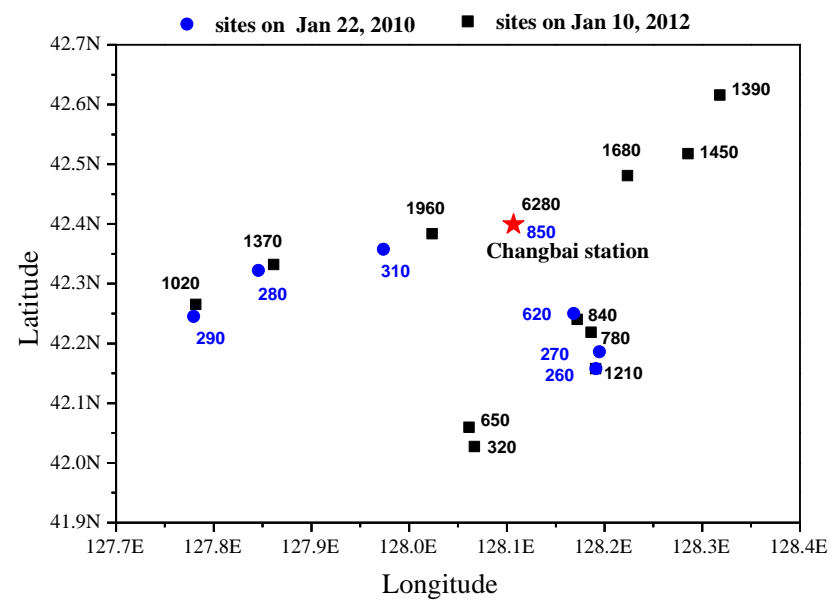

Fig. 4. EC concentrations $\left(\mathrm{ng} \mathrm{g}^{-1}\right)$ around Changbai Mountain from the surveys in January 2010 and 2012.

In contrast to the first survey, the second shows clearly higher values close to the station, decreasing with distance from the station. Moreover, BC concentrations in air from PSAP-ITM show two distinct peaks in the diurnal variation: one in the morning and the other in the evening, particularly for the winter season (manuscript in preparation). This diurnal periodicity in the atmospheric concentrations suggests that at least the region around the Changbai station is influenced by local anthropogenic activities.

\subsection{Scavenging ratio}

The concept of scavenging ratio is based on the simplified assumption that a component's concentration in precipitation is related to its concentration in air (Engelmann, 1971). Thus, the scavenging ratio $\left(\omega_{\mathrm{s}}\right)$ of EC in snow can be calculated on the basis of mass, as follows:

$\omega_{\mathrm{s}}=\frac{C_{\mathrm{EC}, \text { fresh snow }} \cdot \rho_{\mathrm{air}}}{C_{\mathrm{BC}, \text { air }}}$,

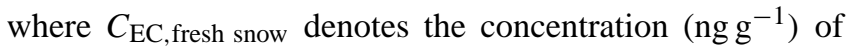
$\mathrm{EC}$ in fresh snow, $C_{\mathrm{BC} \text {,air }} \mathrm{BC}$ concentration $\left(\mu \mathrm{g} \mathrm{m}^{-3}\right)$ in air, 


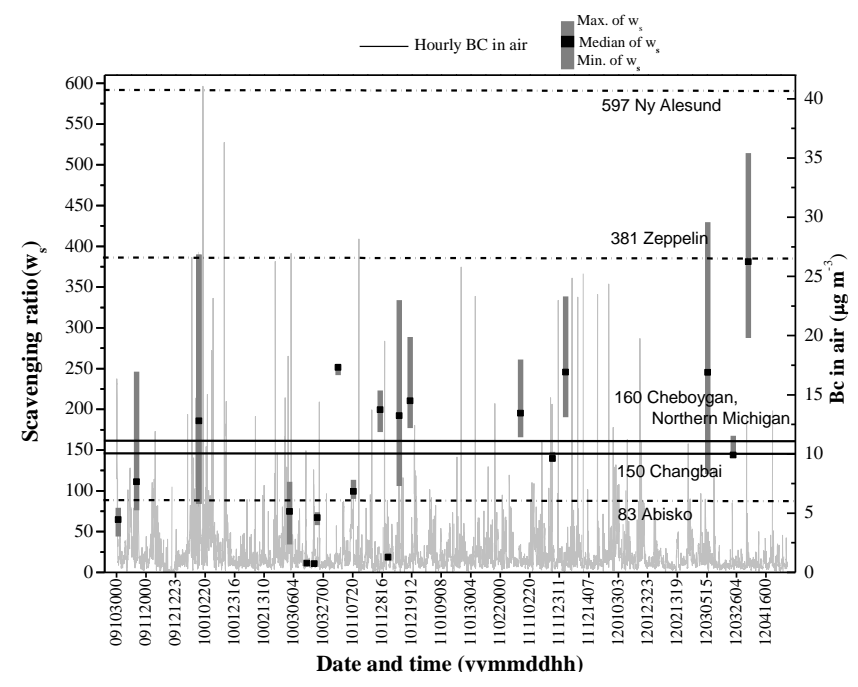

Fig. 5. Hourly mean concentrations of BC $\left(\mu \mathrm{g} \mathrm{m}^{-3}\right)$ in air and EC scavenging ratio from 2009 to 2012. (Data from Zeppelin and NyÅlesund are from Hegg et al., 2011; Abisko from Noone and Clarke, 1988; and Cheboygan from Cadle and Dasch, 1988.)

and $\rho_{\text {air }}$ density of air $\left(1.29 \mathrm{~kg} \mathrm{~m}^{-3}\right), \omega_{\mathrm{s}}$ being dimensionless. The uncertainties in the calculation of $\omega_{\mathrm{s}}$ are the intrinsic accuracy of analysis techniques and the discrepancy between the measurement of BC in air and snow. As our PSAPITM and EC measurements were harmonized, described in Sect. 2.2, concentrations in air and snow could be directly compared. Combining the thermo-optical method and PSAPITM, we considered an uncertainty of $35 \%$ in the calculation of $\omega_{\mathrm{s}}$.

During the observation period, 19 fresh samples were collected. The samples were taken from the upper $5 \mathrm{~cm}$ of the snowpack, but there is often less than $5 \mathrm{~cm}$ equivalent snow thickness for a single precipitation event. Hence, the fresh samples were probably a mixture of old and fresh snow. Thus, our calculation is an upper estimate assuming old snow has higher concentrations of EC than fresh snow. According to the starting and ending times of the snow events recorded by the weather station, the $\mathrm{BC}$ values of the median, first and third quartiles during the event were used for calculating the corresponding median, maximum, and minimum values of $\omega_{\mathrm{S}}$ for the 19 cases (Fig. 5). The upper limit estimate gave a mean $\omega_{\mathrm{s}}$ of $140 \pm 100$, with a median of 150 in the Changbai area. Despite being an upper estimate, it is still comparable with the value of 160 of a rural site of Cheboygan County in northern Michigan (Cadle and Dasch, 1988), but is considerably smaller than the values of Zeppelin and $\mathrm{Ny}$-Ålesund (Hegg et al., 2011), 381 and 597, respectively. Three heavy snow events occurred on 16 March, 21 March, and 3 December 2010, with $21.4,22.2$, and $18.4 \mathrm{~mm}$ water equivalent of precipitation, respectively. The mean $\omega_{\mathrm{s}}$ from these events was 14 , which is the lowest value of the observation set. The highest values were observed on 6 April $2010\left(\omega_{\mathrm{s}}=250\right)$ and

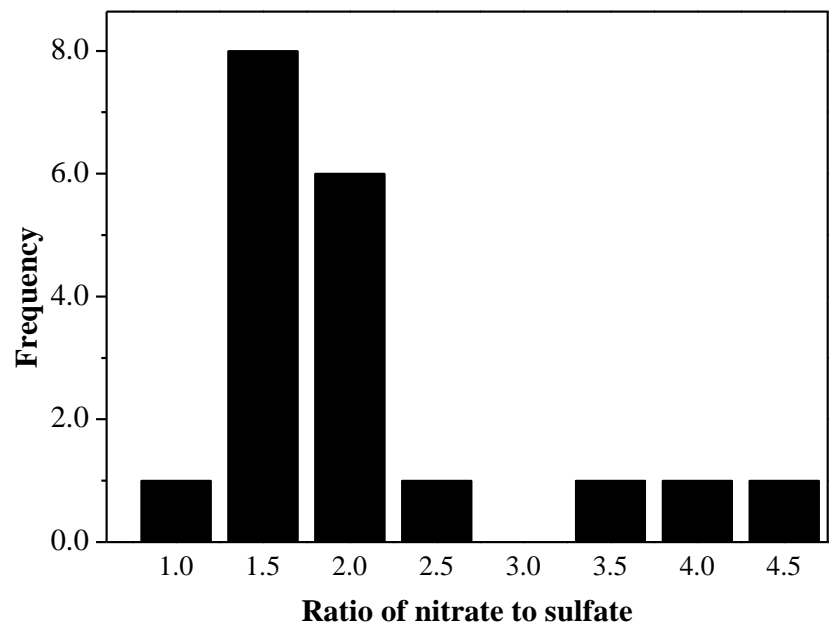

Fig. 6. Frequency of the ratio of nitrate to sulfate in fresh snow.

5 April $2012\left(\omega_{\mathrm{s}}=380\right)$. For these two days, the precipitation values were 4.3 and $0.7 \mathrm{~mm}$ water equivalent, respectively. On these two days, the $\mathrm{BC}$ in air was at relatively low levels of 0.75 and $0.60 \mathrm{\mu g} \mathrm{m}^{-3}$, respectively, with no distinct high peaks (Fig. 5). Both samples were collected during the last fresh snow event for each winter season with relatively warm temperatures; hence, the precipitation process might involve a high cloud liquid water content, which enhanced the scavenging of BC (Cozic et al., 2007).

Raynor and Hayes (1982) indicated that nitrate is preferentially scavenged by snowflakes as compared to sulfate. Scott (1981) showed evidence of riming that originated from clouds with high liquid water content, and determined the values of the scavenging ratios for sulfate aerosols to be 1050 times higher than when the snow had no riming. Hegg et al. (2011) argued that rimed snow is more efficient in removing BC from the atmosphere. When ice crystals form in liquid clouds the so-called Bergeron-Findeisen process may take place. This means that the ice crystals grow at the expense of the cloud droplets. This generates precipitation size crystals with only little BC included from the cloud-forming nuclei. Therefore, the use of the nitrate-to-sulfate ratio indicates the degree of riming in clouds that we can interpret in terms of scavenging efficiency. In the case of rimed snow, the nitrate-to-sulfate ratio is usually less than 0.5 (Mitchell and Lamb, 1989; Duncan, 1992; Endoh et al., 2003). In this study, about $70 \%$ of our samples have a nitrate-to-sulfate ratio ranging from 1.0 to 3.0 (Fig. 6), with a mean value of 1.9. This is higher than that in Abisko for example (Noone and Clarke, 1988) and considerably larger than that in Svalbard (Endoh et al., 2003). Therefore, it is believed that the non-rimed snow process in Changbai is the main process for removing $\mathrm{BC}$ from the atmosphere if a wet process is considered, and that explains the differences in the scavenging ratio in Changbai and the Arctic. 


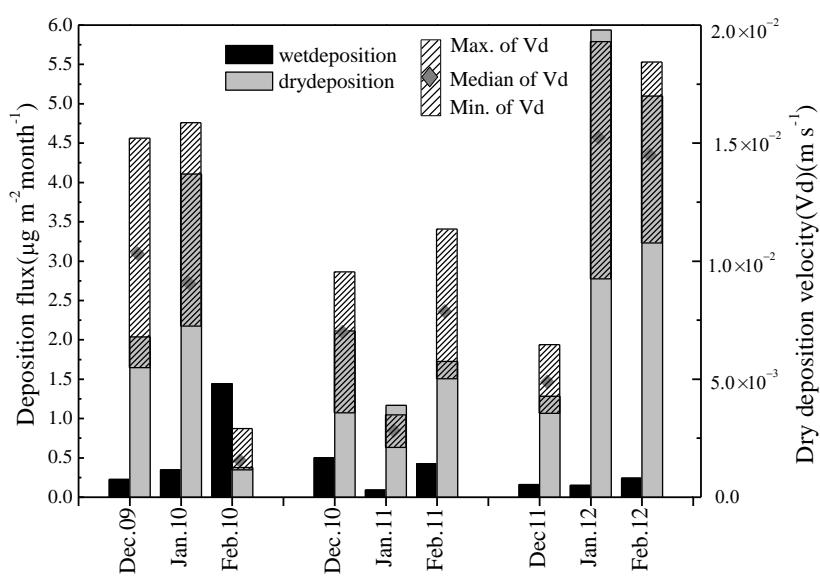

Fig. 7. Dry- and wet-deposition fluxes and dry-deposition velocity $\left(V_{\mathrm{d}}\right)$ of EC on snow surface in winter seasons from 2009 to 2011.

\subsection{EC deposition fluxes and velocities}

Wet-deposition fluxes $\left(F_{\mathrm{wp}}, \mu \mathrm{g} \mathrm{cm}{ }^{-2}\right.$ month $\left.^{-1}\right)$ are calculated using the monthly mean concentration of EC in fresh snow $\left(C_{\mathrm{EC} \text {,fresh snow }}, \mathrm{ng} \mathrm{g}^{-1}\right)$ and the amount of precipitation $(H, \mathrm{~cm})$, as follows:

$F_{\mathrm{wp}}=\frac{C_{\mathrm{EC}, \text { fresh snow }}}{1000 \cdot H}$.

A $30 \%$ uncertainty should be considered in the case of the thermo-optical method. Wet-deposition fluxes range from 0.09 to $1.44 \mu \mathrm{g} \mathrm{cm}^{-2}$ month $^{-1}$ (Table 2 and Fig. 7), with a mean value of $0.47 \pm 0.37 \mu \mathrm{g} \mathrm{cm}^{-2}$ month $^{-1}$ in NovemberApril of 2009-2012, which is comparable to the values of $0.05-2.5 \mu \mathrm{g} \mathrm{cm}^{-2}$ month $^{-1}$ reported earlier in Europe (Ogren et al., 1984; Armalis, 1999).

Dry deposition is generally more difficult to measure directly and depends on many factors including meteorological conditions, characteristics of the pollutants being deposited (e.g., different gaseous chemical and particle size), and the surface on which deposition occurs (Jurado et al., 2008). Here, the estimate is obtained by calculating the differences of EC in snow between two measurements without any precipitation. The calculations cover the period of DecemberFebruary, as during this period, all recorded temperatures are below the freezing point (Fig. 8), which implies that no melting events modify the surface concentration. Thus, any increase in EC concentration between the two samples is attributed to dry deposition or a potential increase in EC due to snow evaporation. The flux of snow evaporation $\left(S_{\mathrm{ep}}\right)$ is estimated as follows:

$S_{\mathrm{ep}}=\frac{\sum_{i=1}^{n_{2}} e_{i}-\sum_{i=1}^{n_{1}} e_{i}}{10 \cdot \Delta t}$

where $n_{1}$ denotes the number of days without precipitation from the first snow sample, $n_{2}$ the number of days without precipitation until the second snow sample, $e_{i}$ the daily evaporation rate $\left(\mathrm{mm} \mathrm{day}^{-1}\right), \Delta t$ the time interval in days, and $S_{\text {ep }}$ an estimate of evaporation in $\mathrm{cm} \mathrm{day}^{-1}$ during the time interval of interest. We can now estimate the increase in EC flux from snow evaporation during the considered interval in the snow surface by using the following:

$F_{\text {ep }}=\frac{C_{\mathrm{EC}, \text { fresh snow }}}{1000} \cdot S_{\mathrm{ep}}$,

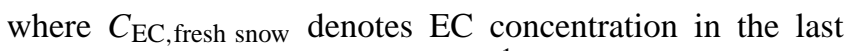
fresh snow sample collected $\left(\mathrm{ng} \mathrm{g}^{-1}\right) . F_{\text {ep }}$ is then expressed in $\mu \mathrm{g} \mathrm{cm}^{-2}$ day $^{-1}$ over the period of interest. For simplicity, we integrate over each month, as presented in Table 2 $\left(\mu \mathrm{g} \mathrm{cm}^{-2}\right.$ month $\left.^{-1}\right) . F_{\text {ep }}$ denotes the potential increase in EC due to snow sublimation; hence, it has to be subtracted from the dry-deposition flux $\left(F_{\mathrm{dp}}, \mu \mathrm{g} \mathrm{cm}{ }^{-2} \mathrm{day}^{-1}\right)$, calculated as follows:

$F_{\mathrm{dp}}=\left(\frac{\left(\frac{C_{\mathrm{EC}_{2}}}{1000} \cdot \mathrm{Rho}_{2}\right)-\left(\frac{C_{\mathrm{EC}_{1}}}{1000} \cdot \mathrm{Rho}_{1}\right)}{\Delta t}\right)-F_{\mathrm{ep}}$,

where $C_{\mathrm{EC} 1}$ and $C_{\mathrm{EC} 2}$ denote the concentration $\left(\mathrm{ng} \mathrm{g}^{-1}\right)$ of $\mathrm{EC}$ in the first and second snow samples, respectively, and $\Delta t$ represents the time interval. $\mathrm{Rho}_{1}$ and $\mathrm{Rho}_{2}$ denote the two correction factors required to convert the $5 \mathrm{~cm}$ sample into a mass of water in order to correspond to the measurement unit of $C_{\mathrm{EC}}$. Fresh snow in Changbai is often light, on the order of $100-150 \mathrm{~kg} \mathrm{~m}^{-3}$, and during the period of November to February, the temperature is considerably low, implying that the snow will not evolve rapidly, particularly on a weekly sampling basis. We estimate the snow density ranging from 150 to $250 \mathrm{~kg} \mathrm{~m}^{-3}$ during our sampling. For simplicity, we set the snow density at $200 \mathrm{~kg} \mathrm{~m}^{-3}$ for all measurements so that the corrected factor, for our $5 \mathrm{~cm}$ sample, is $\mathrm{Rho}_{1}=\mathrm{Rho}_{2}=\frac{5}{\frac{\rho_{\text {water }}}{\rho_{\text {snow }}}}=1$. These factors will modify the dry deposition as they directly depend on the snow density. Differences in densities between two samples will also modify our results.

The major uncertainties of the calculated $F_{\mathrm{dp}}$ are associated with the observations from the evaporation pan. Lowe et al. (2009) showed that the $95 \%$ probability interval surrounding the estimates of evaporation was as large as $40 \%$ of the best estimate. Thus, we estimate a $70 \%$ uncertainty for $F_{\mathrm{dp}}$, without taking into account the uncertainties on the snow density variations, which would probably increase our estimated uncertainty. All fluxes and uncertainties of the dry deposition of EC are shown in Table 2 and Fig. 7. Dry-deposition fluxes range from 0.38 to $5.94 \mathrm{\mu g} \mathrm{cm}^{-2}$ month $^{-1}$, with the mean of $2.65 \pm 1.93 \mu \mathrm{g} \mathrm{cm}^{-2}$ month $^{-1}$ from December to February of 2009-2012, which is more than six times that from wet deposition $\left(0.40 \pm 0.41 \mu \mathrm{g} \mathrm{cm}^{-2}\right.$ month $\left.^{-1}\right)$ during the same time period. It is $60-100$ times more than what is dry-deposited over Himalayan glaciers during the dry pre-monsoon periods, according to the values given in Yasunari et al. (2013). 
Table 2. Deposition fluxes and dry deposition velocity of EC on snow surface during snow seasons 2009-2011 (uncertainty). The blank cells correspond to periods with no possibility of the estimation of snow evaporation because of melting (and therefore dry deposition of EC).

\begin{tabular}{|c|c|c|c|c|c|c|c|c|c|c|}
\hline \multirow[t]{2}{*}{ Date } & \multicolumn{2}{|c|}{$\begin{array}{l}\text { EC wet deposition } \\
\left(\mu \mathrm{g} \mathrm{cm}^{-2} \text { month }^{-1}\right)\end{array}$} & \multicolumn{2}{|c|}{$\begin{array}{l}\text { EC dry deposition } \\
\left(\mu \mathrm{g} \mathrm{cm}^{-2} \text { month }^{-1}\right)\end{array}$} & \multicolumn{2}{|c|}{$\begin{array}{c}\text { EC increase due to snow } \\
\left(\mu \mathrm{g} \mathrm{cm}^{-2} \text { month }^{-1}\right) \\
\text { evaporation }\end{array}$} & \multirow[b]{2}{*}{ Mean } & \multicolumn{3}{|c|}{$\begin{array}{l}\text { EC dry deposition velocity } \\
\mathrm{m} \mathrm{s}^{-1}\end{array}$} \\
\hline & $\left(F_{\mathrm{wp}}\right)$ & Uncert.* & $\left(F_{\mathrm{dp}}\right)$ & Uncert.* & $\left(F_{\mathrm{ep}}\right)$ & Uncert.* & & Median & $25 \%$ & $75 \%$ \\
\hline $9 \mathrm{Nov}$ & 0.96 & 0.29 & & & & & & & & \\
\hline $9 \mathrm{Dec}$ & 0.23 & 0.07 & 2.04 & 1.42 & 0.32 & 0.23 & $1.05 \times 10^{-2}$ & $1.03 \times 10^{-2}$ & $5.49 \times 10^{-3}$ & $1.52 \times 10^{-2}$ \\
\hline $10 \mathrm{Jan}$ & 0.35 & 0.11 & 4.11 & 2.87 & 0.21 & 0.15 & $9.41 \times 10^{-3}$ & $9.06 \times 10^{-3}$ & $7.25 \times 10^{-3}$ & $1.59 \times 10^{-2}$ \\
\hline $10 \mathrm{Feb}$ & 1.44 & 0.43 & 0.38 & 0.26 & 0.35 & 0.25 & $1.21 \times 10^{-3}$ & $1.55 \times 10^{-3}$ & $1.16 \times 10^{-3}$ & $2.90 \times 10^{-3}$ \\
\hline $10 \mathrm{Mar}$ & 0.21 & 0.06 & & & & & & & & \\
\hline $10 \mathrm{Apr}$ & 0.62 & 0.19 & & & & & & & & \\
\hline Average 2009 season & 0.63 & 0.19 & 2.17 & 1.52 & 0.30 & 0.21 & $7.05 \times 10^{-3}$ & $6.98 \times 10^{-3}$ & $4.63 \times 10^{-3}$ & $1.13 \times 10^{-2}$ \\
\hline $10 \mathrm{Nov}$ & 0.2 & 0.06 & & & & & & & & \\
\hline $10 \mathrm{Dec}$ & 0.5 & 0.15 & 2.11 & 1.48 & 0.15 & 0.11 & $3.92 \times 10^{-3}$ & $6.99 \times 10^{-3}$ & $3.58 \times 10^{-3}$ & $9.55 \times 10^{-3}$ \\
\hline $11 \mathrm{Jan}$ & 0.09 & 0.03 & 1.17 & 0.82 & 0.22 & 0.15 & $2.06 \times 10^{-3}$ & $2.82 \times 10^{-3}$ & $2.11 \times 10^{-3}$ & $3.49 \times 10^{-3}$ \\
\hline $11 \mathrm{Feb}$ & 0.43 & 0.13 & 1.73 & 1.21 & 0.42 & 0.29 & $5.66 \times 10^{-3}$ & $7.88 \times 10^{-3}$ & $5.02 \times 10^{-3}$ & $1.14 \times 10^{-2}$ \\
\hline $11 \mathrm{Mar}$ & 0.25 & 0.08 & & & & & & & & \\
\hline Average 2010 season & 0.29 & 0.09 & 1.67 & 1.17 & 0.26 & 0.19 & $3.88 \times 10^{-3}$ & $5.90 \times 10^{-3}$ & $3.57 \times 10^{-3}$ & $8.13 \times 10^{-3}$ \\
\hline $11 \mathrm{Nov}$ & 0.86 & 0.26 & & & & & & & & \\
\hline $11 \mathrm{Dec}$ & 0.16 & 0.05 & 1.28 & 0.90 & 0.25 & 0.17 & $3.68 \times 10^{-3}$ & $4.88 \times 10^{-3}$ & $3.55 \times 10^{-3}$ & $6.46 \times 10^{-3}$ \\
\hline $12 \mathrm{Jan}$ & 0.15 & 0.05 & 5.94 & 4.16 & 0.22 & 0.15 & $1.03 \times 10^{-2}$ & $1.52 \times 10^{-2}$ & $9.25 \times 10^{-3}$ & $1.92 \times 10^{-2}$ \\
\hline $12 \mathrm{Feb}$ & 0.24 & 0.07 & 5.10 & 3.57 & 0.23 & 0.16 & $1.13 \times 10^{-2}$ & $1.45 \times 10^{-2}$ & $1.08 \times 10^{-2}$ & $1.84 \times 10^{-2}$ \\
\hline $12 \mathrm{Mar}$ & 0.52 & 0.16 & & & & & & & & \\
\hline $12 \mathrm{Apr}$ & 0.85 & 0.26 & & & & & & & & \\
\hline Average 2011 season & 0.37 & 0.11 & 4.11 & 2.87 & 0.23 & 0.16 & $8.39 \times 10^{-3}$ & $1.15 \times 10^{-2}$ & $7.86 \times 10^{-3}$ & $1.47 \times 10^{-2}$ \\
\hline Average all seasons & 0.47 & 0.14 & 2.65 & 1.85 & 0.26 & 0.18 & $6.44 \times 10^{-3}$ & $8.14 \times 10^{-3}$ & $5.35 \times 10^{-3}$ & $1.14 \times 10^{-2}$ \\
\hline
\end{tabular}

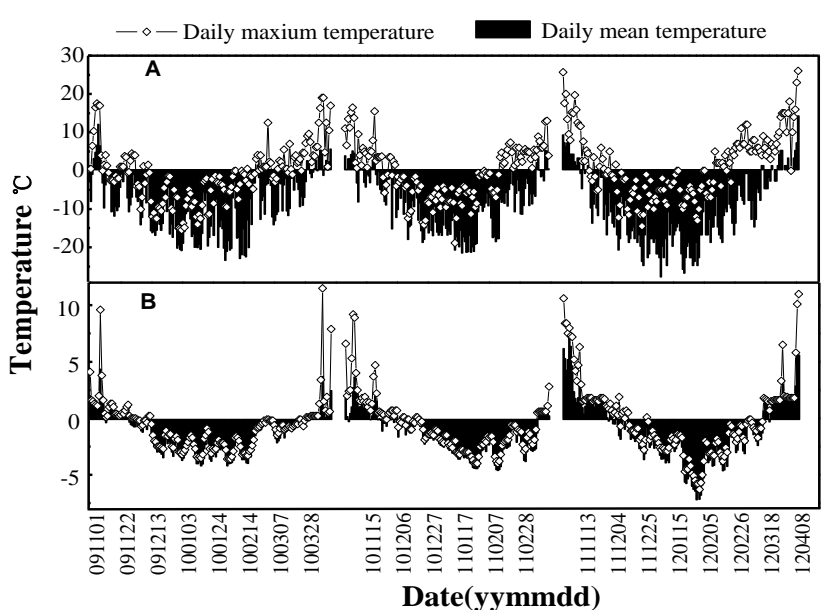

Fig. 8. Daily mean and maximum temperatures of air temperature near snow surface (A) and snow-soil interface (B) from 2009 to 2012.

For the period of December-February, the percentages of wet- to dry-deposition flux are $28 \%, 17 \%$, and $9 \%$ for 2009-2010, 2010-2011, and 2011-2012, respectively. Overall, $87 \%$ of the total EC in snow is attributed to dry deposition during December-February of 2009-2012, indicating that the dry-deposition process is the major contribution of $\mathrm{EC}$ in snow in Changbai, northeastern China.
The dry-deposition velocity $V_{\mathrm{d}}$ is calculated by dividing the dry-deposition flux $F_{\mathrm{dp}}$ with the BC ambient concentration, expressed as follows:

$V_{\mathrm{d}}=\frac{F_{\mathrm{dp}}}{C_{\mathrm{Bc}, \text { air }}}$,

where $V_{\mathrm{d}}\left(\mathrm{m} \mathrm{s}^{-1}\right)$ denotes the dry-deposition velocity of EC, $F_{\mathrm{dp}}\left(\mu \mathrm{g} \mathrm{cm}^{-2}\right.$ day $\left.^{-1}\right)$ the EC dry-deposition flux, and $C_{\mathrm{BC} \text {,air }}$ $\left(\mu \mathrm{g} \mathrm{m}^{-3}\right)$ the $\mathrm{BC}$ concentration in air. The timing corresponds to the sampling time used for estimating dry deposition. For simplicity, the measurements have then been integrated over a month (Table 2). The BC values of the median, first, and third quartiles during this period are used for calculating the corresponding median, maximum, and minimum values for $V_{\mathrm{d}}$, respectively. It is likely that the uncertainty in the derived deposition velocities is at least on the order of a factor of two. However, considering the large range reported in the literature from $1.0 \times 10^{-5}$ to $1.0 \times 10^{-2} \mathrm{~m} \mathrm{~s}^{-1}$ (Dovland and Eliassen, 1976; Bergin et al., 1995; Yasunari et al., 2013), we believe that our estimates contribute to lowering of the overall uncertainty. The monthly dry-deposition velocity is shown in Fig. 7 and Table 2, and the mean value is $6.44 \times 10^{-3} \mathrm{~m} \mathrm{~s}^{-1}$, with a median of $8.14 \times 10^{-3} \mathrm{~m} \mathrm{~s}^{-1}$ during December-February, 2009-2012. The knowledge about the dry-deposition velocity of EC is particularly poor as compared to that about other pollutants; therefore, this estimate may serve to improve simulations in climate modeling in this area. 


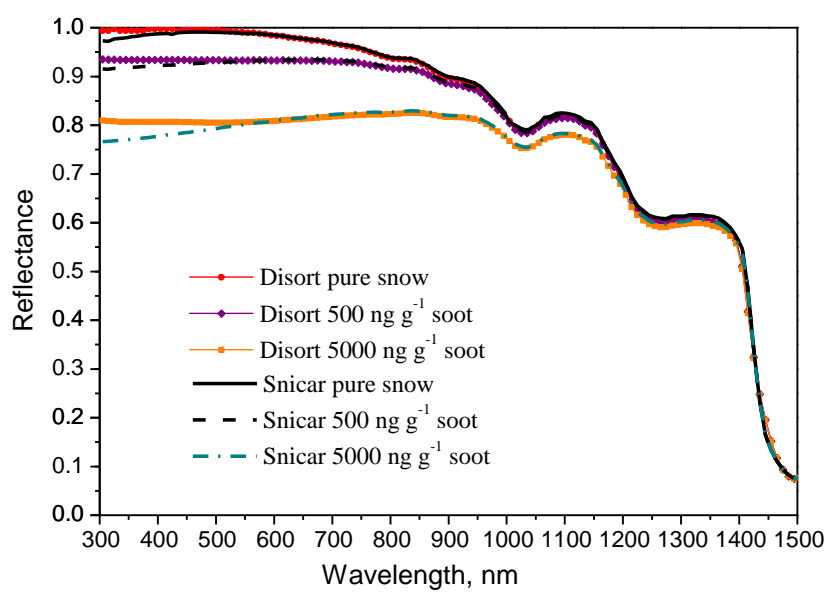

Fig. 9. Comparison of SNICAR-Online and DISORT calculated reflectances for pure snow and two contaminated snowpacks by wet deposition of BC.

\section{Implications for snow albedo}

Is the distinction between dry and wet deposition important considering the radiative impact by $\mathrm{BC}$ in the snowpack? Our results show that about $87 \%$ of the BC deposited over the surface snow in the Changbai station is due to dry deposition, while the rest is wet-deposited mostly by a non-rimed process. Our sampling represents the upper $5 \mathrm{~cm}$ of the snowpack, which will be our reference snow depth. In the case of wet deposition, BC is mixed within the snow, and the optical properties of the medium are given as a mass-weighted mixture of the optical properties of ice and BC. Considering dry deposition, $\mathrm{BC}$ will predominantly stay at the surface. If the $\mathrm{BC}$ particles are on the surface, the radiative impact will be greater than if it were mixed deeper into the snow. In this case, absorption should be stronger and more uniform over the visible spectrum, considering that $\mathrm{BC}$ absorbs uniformly over this spectrum. We want to test this hypothesis in order to estimate the radiative impact of such BC concentrations and the effect of the dry- and wet-deposition processes.

Two different models are used for this purpose: SNICAROnline (Flanner et al., 2007) and DISORT (Stamnes et al., 1988). SNICAR-Online only calculates the albedo for a single snow layer; therefore, $\mathrm{BC}$ can only be modeled as wet deposition. In DISORT, we can use several snow layers and simulate the effect of dry deposition. The idea is to move all the $\mathrm{BC}$ from the first $5 \mathrm{~cm}$ and concentrate it in a very thin layer in order to exaggerate dry deposition. This layer should contain all BC in the sample, so if the thickness of the layer were $1 \mathrm{~mm}$, it should contain 50 times more BC; $500 \mathrm{ng} \mathrm{g}^{-1}$ of wet deposition in a $5 \mathrm{~cm}$-thick layer corresponds to a $1 \mathrm{~mm}$-thick surface layer with $25000 \mathrm{ng} \mathrm{g}^{-1} \mathrm{BC}$ on top of a $4.9 \mathrm{~cm}$-thick second layer with no $\mathrm{BC}$ at all.

We will use the term reflectance here, even if the correct term for our calculations is directional hemispherical

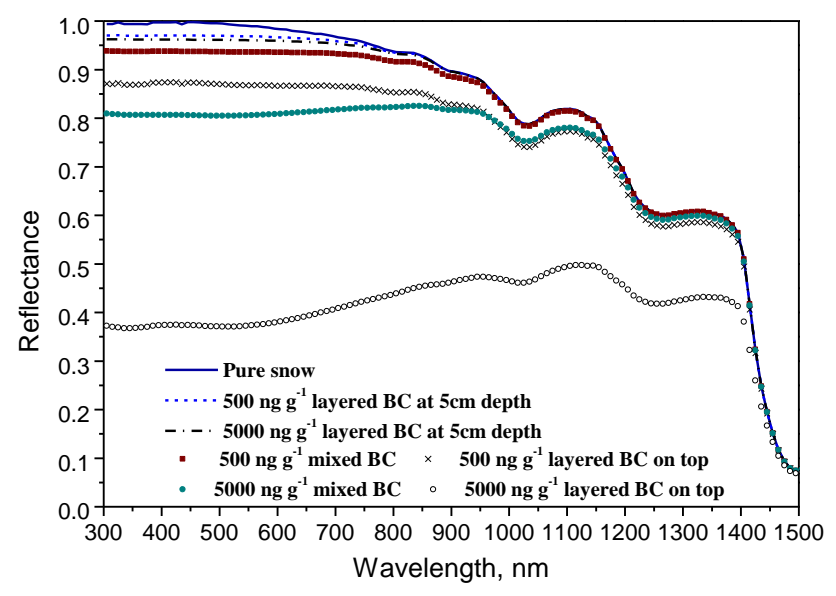

Fig. 10. Effect of $B C$ on the snow reflectance for 500 and $5000 \mathrm{ng} \mathrm{g}^{-1}$ of soot included as layered on top, layered at $5 \mathrm{~cm}$ depth and mixed.

reflectance (Schaepman-Strub et al., 2006). We will also use the term mixed $\mathrm{BC}$ for snow when $\mathrm{BC}$ has been wetdeposited, while the term layered $\mathrm{BC}$ will be used when considering $\mathrm{BC}$ that is dry-deposited over the snow surface. The physical snow properties for the case study are as follows (not necessarily identical to our Changbai case): grain size of $65 \mu \mathrm{m}$, snow density of $200 \mathrm{~kg} \mathrm{~m}^{-3}$, snow thickness of $1 \mathrm{~m}$, direct solar illumination at a zenith angle of $60^{\circ}$, and external mixing of snow and BC. In both models, BC is included as uncoated particles with the index of refraction of 1.95-0.79i recommended by Bond and Bergstrom (2006).

Figure 9 shows a comparison of the calculated reflectance between the two models for three cases: (i) pure snowpack, (ii) a snowpack with $500 \mathrm{ng} \mathrm{g}^{-1}$, and (iii) a snowpack with $5000 \mathrm{ng} \mathrm{g}^{-1}$ (the two latter for mixed BC). The wavelength range is limited to $300-1500 \mathrm{~nm}$ for clarity. As expected the two models agree well with the exception of the blue and near-ultraviolet region, due to slightly different ice refractive indices used in the two models. However, this will not affect the overall result of the comparison. As the models agree well, we will use DISORT for two extreme cases where the $\mathrm{BC}$ was either located at the very top of the snow surface or as a layer buried $5 \mathrm{~cm}$ below the air-snow interface, as well as a well mixed situation. Figure 10 shows that the layered $\mathrm{BC}$ at $5 \mathrm{~cm}$ depth is considerably less effective than the other simulations because a major part of the incoming light is already absorbed or reflected at the upper snow layer. The snow reflectance decreases more when $\mathrm{BC}$ is mixed and even more if $\mathrm{BC}$ is layered and stays at the snow-air interface.

Clearly, these simulations are very idealistic, but they highlight the importance of the exact location of $\mathrm{BC}$ in the upper layers of the snow. Compared with $500 \mathrm{ng} \mathrm{g}^{-1} \mathrm{BC}$ concentrated in a layer at $5 \mathrm{~cm}$ depth, the snow reflectance is decreased by $2.3 \%$ and $7.8 \%$ compared to if the same amount were well mixed or located at the top, respectively. Taking 
into account the daily average incoming solar irradiance at Changbai of $450 \mathrm{~W} \mathrm{~m}^{-2}$ in mid-March during clear sky conditions, the surface layered $\mathrm{BC}$ enhances the absorption by about $25 \mathrm{~W} \mathrm{~m}^{-2}$ per day as compared to the mixed $\mathrm{BC}$ case. Assuming a snow surface temperature of $0^{\circ}, 25 \mathrm{~W} \mathrm{~m}^{-2}$ of the absorbed energy corresponds to a melting rate of approximately $1.3 \mathrm{~mm} \mathrm{~h}^{-1}$ of snow, or a sublimation rate of $0.2 \mathrm{~mm} \mathrm{~h}^{-1}$ (snow density of $200 \mathrm{~kg} \mathrm{~m}^{-3}$ ). Both values are fairly high but serve to emphasize the role of the distribution of $\mathrm{BC}$ in the surface snow.

\section{Conclusions}

Measurements of elemental carbon in the snow surface at the Changbai station, northeastern China, were performed over three snow seasons, and the values spanned from 7 to $7640 \mathrm{ng} \mathrm{g}^{-1}$ with a mean of $1000 \pm 1500 \mathrm{ng} \mathrm{g}^{-1}$. The scavenging ratio of EC was derived to be 140 on average, which was in the range of the values reported in the rural area at the same latitude and similar to those reported for Arctic areas. Chemical analyses indicated that non-rimed processes tended to be the most common removal mechanisms of EC from the atmosphere when wet deposition was considered. The wet-deposition flux was estimated to be $0.47 \pm 0.37 \mu \mathrm{g} \mathrm{cm}^{-2}$ month $^{-1}$ in winter, which was three times lower than the dry flux, estimated to be $2.65 \pm 1.93 \mu \mathrm{g} \mathrm{cm}^{-2} \mathrm{month}^{-1}$. The mean dry-deposition velocity was estimated to be $6.44 \times 10^{-3} \mathrm{~m} \mathrm{~s}^{-1}$, with a median of $8.14 \times 10^{-3} \mathrm{~m} \mathrm{~s}^{-1}$. For the three years studied, $87 \%$ of the EC in the surface snow was attributed to dry deposition. Finally, the radiative transfer calculations showed that drydeposited BC, at the air-snow interface, strongly enhanced the amount of absorbing radiation as compared to the same mass of BC that was wet-deposited, leading to an increase in the melting rate of the snowpack.

Acknowledgements. This study is a part of the "Long-range transport of black carbon and the effect on snow albedo in north-east China and in the Arctic (LOTUS)" project financed by the Research Council of Norway (project number 193717). We express our sincere gratitude to our co-workers S. Han and $\mathrm{H}$. Xu at the Changbai station for their help with the collection of snow samples and the filtering procedure. We also acknowledge the Swedish research council FORMAS for their support via the project Black and White, and the Open Science Foundation of the State Key Laboratory of Atmospheric Boundary Layer Physics and Atmospheric Chemistry at the Institute of Atmospheric Physics, Chinese Academy of Sciences. We acknowledge J. Svensson for help with the EC thermo-optical measurements. Support from CRAICC (Nordic Centre of Excellence) is also acknowledged.

Edited by: P. Quinn

\section{References}

Arctic Monitoring and Assessment Programme (AMAP): The Impact of Black Carbon on Arctic Climate (2011), edited by: Quinn, P. K., Stohl, A., Arneth, A., Berntsen, T., Burkhart, J. F., Christensen, J., Flanner, M., Kupiainen, K., Lihavainen, H., Shepherd, M., Shevchenko, V., Skov, H., and Vestreng, V., Oslo, ISBN-97882-7971-069-1, 2011.

Armalis, S.: Wet deposition of elemental carbon in Lithuania, Sci. Total Environ., 239, 89-93, 1999.

Bachmann, J.: Black Carbon: A Science/Policy Primer, Arlington, VA: Pew Center on Global Climate Change, 2009.

Bergin, M. H., Jaffrezo, J.-L., Davidson, C. I., Dibb, J. E., Pandis, S. N., Hillamo, R., Maenhaut, W., Kuhns, H. D., and Makela, T.: The contributions of snow, fog, and dry deposition to the summer flux of anions and cations at Summit, Greenland, J. Geophys. Res., 100, 16275-16288, 1995.

Bond, T. C., Anderson, T. L., and Campbell, D.: Calibration and intercomparison of filter-based measurements of visible light absorption by aerosols, Aerosol Sci. Tech., 30, 582-600, doi:10.1080/027868299304435, 1999.

Bond, T. C. and Bergstrom, R. W.: Light absorption by carbonaceous particles: An investigative review, Aerosol Sci, Tech,, 40, 27-67, doi:10.1080/02786820500421521, 2006.

Bond, T. C., Doherty, S. J., Fahey, D. W., Forster, P. M., Berntsen, T., DeAngelo, B. J., Flanner, M. G., Ghan, S., Kärcher, B., Koch, D., Kinne, S., Kondo, Y., Quinn, P. K., Sarofim, M. C., Schultz, M. G., Schulz, M., Venkataraman, C., Zhang, H., Zhang, S., Bellouin, N., Guttikunda, S. K., Hopke, P. K., Jacobson, M. Z., Kaiser, J. W., Klimont, Z., Lohmann, U., Schwarz, J. P., Shindell, D., Storelvmo, T., Warren, S. G., and Zender, C. S.: Bounding the role of black carbon in the climate system: A scientific assessment, J. Geophys. Res.-Atmos., 118, 5380-5552, doi:10.1002/jgrd.50171, 2013.

Box, J. E. and Steffen, K.: Sublimation on the Greenland ice sheet from automated weather station observations, J. Geophys. Res., 106, 33965-33981, 2001.

Cadle, S. and Dasch, J.: Wintertime concentrations and sinks of atmospheric particulate carbon at a rural location in Northern Michigan, Atmos. Environ., 22, 1373-1381, 1988.

Cavalli, F., Viana, M., Yttri, K. E., Genberg, J., and Putaud, J.-P.: Toward a standardised thermal-optical protocol for measuring atmospheric organic and elemental carbon: the EUSAAR protocol, Atmos. Meas. Tech., 3, 79-89, doi:10.5194/amt-3-79-2010, 2010.

Cerqueira, M., Pio, C., Legrand, M., Puxbaum, H., Kasper-Gieblc, A., Afonso, J., Preunkert, S., Gelencsér, A., and Fialho, P.: Particulate carbon in precipitation at European back ground sites, Aerosol Sci., 41, 51-61, 2010.

Chow, J. C., Watson, J. G., Chen, L. W. A., Chang, M. C. O., Robinson, N. F., Trimble, D., and Kohl, S.: The IMPROVE-A temperature protocol for thermal/optical carbon analysis: maintaining consistency with a long-term database, J. Air Waste Manage. Assoc., 57, 1014-1023, doi:10.3155/1047-3289.57.9.1014, 2007.

Cozic, J., Verheggen, B., Mertes, S., Connolly, P., Bower, K., Petzold, A., Baltensperger, U., and Weingartner, E.: Scavenging of black carbon in mixed phase clouds at the high alpine site Jungfraujoch, Atmos. Chem. Phys., 7, 1797-1807, doi:10.5194/acp-7-1797-2007, 2007. 
Doherty, S. J., Warren, S. G., Grenfell, T. C., Clarke, A. D., and Brandt, R. E.: Light-absorbing impurities in Arctic snow, Atmos. Chem. Phys., 10, 11647-11680, doi:10.5194/acp-1011647-2010, 2010.

Dovland, H. and Eliassen, A.: Dry deposition on a snow surface, Atmos. Environ., 10, 783-785, 1976.

Duncan, L.: Chemistry of rime and snow collected at a site in the Central Washington Cascades, Environ. Sci. Technol., 26, 61-66, 1992.

Endoh, T., Takahashi, T., Noguchi, I., Koga, S., and Kurita, N.: Polar night investigation of chemical components in fresh snow particles and aerosol/gas in the atmosphere at Ny Ålesund (On abilities of $\mathrm{NO}_{3}$ in solid precipitation participating in long range transport, Tohoku Geophys. J., 36, 486-492, 2003.

Engelmann, R. J.: Scavenging prediction using ratios of concentrations in air and precipitation, J. Appl. Meteorol., 10, 493-497, 1971.

Flanner, M. G., Zender, C. S., Randerson, J. T., and Rasch, P. J.: Present-day climate forcing and response from black carbon in snow, J. Geophys. Res.-Atmos., 112, D11202, doi:10.1029/2006jd008003, 2007.

Flanner, M. G., Zender, C. S., Hess, P. G., Mahowald, N. M., Painter, T. H., Ramanathan, V., and Rasch, P. J.: Springtime warming and reduced snow cover from carbonaceous particles, Atmos. Chem. Phys., 9, 2481-2497, doi:10.5194/acp-9-24812009, 2009.

Forsström, S., Ström, J., Pedersen, C. A., Isaksson, E., and Gerland S.: Elemental carbon distribution in Svalbard snow, J. Geophys. Res., 114, D19112, doi:10.1029/2008JD011480, 2009.

Hansen, J. and Nazarenko, L.: Soot climate forcing via snow and ice albedos, Proc. Natl. Acad. Sci. USA, 101, 423-428, doi:10.1073/pnas.2237157100, 2004.

Hegg, D. A., Clarke, A. D., Doherty, S. J., and Ström, J.: Measurements of black carbon aerosol washout ratio on Svalbard, Tellus, 63, 891-900, 2011.

Hood, E., Williams, M., and Cline, D.: Sublimation from a seasonal snowpack at a continental, mid-latitude alpine site, Hydrol. Process., 13, 1781-1797, 1999.

Huang, J., Fu, Q., Zhang, W., Wang, X., Zhang, R., Ye, H., and Warren, S. G.: Dust and black carbon in seasonal snow across northern China, B. Am. Meteorol. Soc., 92, 175-181, 2011.

Jacobson, M. Z.: Climate response of fossil fuel and biofuel soot, accounting for soot's feedback to snow and sea ice albedo and emissivity, J. Geophys. Res., 109, D21201, doi:10.1029/2004JD004945, 2004.

Jurado E., Dachs, J., Duarte, C., and Simó R.: Atmospheric deposition of organic and black carbon to the global oceans, Atmos. Environ., 42, 7931-7939, 2008.

Koch, D., Schulz, M., Kinne, S., McNaughton, C., Spackman, J. R., Balkanski, Y., Bauer, S., Berntsen, T., Bond, T. C., Boucher, O., Chin, M., Clarke, A., De Luca, N., Dentener, F., Diehl, T., Dubovik, O., Easter, R., Fahey, D. W., Feichter, J., Fillmore, D., Freitag, S., Ghan, S., Ginoux, P., Gong, S., Horowitz, L., Iversen, T., Kirkevåg, A., Klimont, Z., Kondo, Y., Krol, M., Liu, X., Miller, R., Montanaro, V., Moteki, N., Myhre, G., Penner, J. E., Perlwitz, J., Pitari, G., Reddy, S., Sahu, L., Sakamoto, H., Schuster, G., Schwarz, J. P., Seland, Ø., Stier, P., Takegawa, N., Takemura, T., Textor, C., van Aardenne, J. A., and Zhao, Y.: Corrigendum to "Evaluation of black carbon estimations in global aerosol models" published in Atmos. Chem. Phys., 9, 9001-9026, 2009, Atmos. Chem. Phys., 10, 79-81, doi:10.5194/acp-10-79-2010, 2010.

Krecl, P., Strom, J., and Johansson, C.: Carbon content of atmospheric aerosols in a residential area during the wood combustion season in Sweden, Atmos. Environ., 41, 6974-6985, doi:10.1016/j.atmosenv.2007.06.025, 2007.

Lowe, L. D., Angus, J., Rory, W., Nathan, J., Etchells, T., and Malano, H. M.: Evaporation from water supply reservoirs: An assessment of uncertainty, J. Hydrol., 376, 261-274, 2009.

Menon, S., Koch, D., Beig, G., Sahu, S., Fasullo, J., and Orlikowski, D.: Black carbon aerosols and the third polar ice cap, Atmos. Chem. Phys., 10, 4559-4571, doi:10.5194/acp-10-4559-2010, 2010.

Ming, J., Cachier, H., Xiao, C., Qin, D., Kang, S., Hou, S., and $\mathrm{Xu}$, J.: Black carbon record based on a shallow Himalayan ice core and its climatic implications, Atmos. Chem. Phys., 8, 13431352, doi:10.5194/acp-8-1343-2008, 2008.

Ming, J., Xiao, C., Du, Z., and Yang, X.: An overview of black carbon deposition in High Asia glaciers and its impacts on radiation balance, Adv. Water Resour., 55, 80-87, 2012.

Mitchell, D. L. and Lamb, D.: Influence of riming on the chemical composition of snow in winter orographic storms, J. Geophys. Res., 94, 14831-14840, 1989.

Noone, K. J. and Clarke A. D.: Soot scavenging measurement in Arctic snowfall, Atmos. Environ., 22, 2773-2778, 1988.

Novakov, T., Ramanathan, V., Hansen, J. E., Kirchstetter, T. W., Sato, M., Sinton, J. E., and Sathaye, J. A.: Large historical changes of fossil-fuel black carbon aerosols, Geophys. Res. Lett., 30, 1324, doi:10.1029/2002GL016345, 2003.

Ogren, J. A.: Wet deposition of elemental carbon and sulfate in Sweden, Tellus, 36, 262-271, 1984.

Petzold, A., Ogren, J. A., Fiebig, M., Laj, P., Li, S.-M., Baltensperger, U., Holzer-Popp, T., Kinne, S., Pappalardo, G., Sugimoto, N., Wehrli, C., Wiedensohler, A., and Zhang, X.-Y.: Recommendations for reporting "black carbon" measurements, Atmos. Chem. Phys., 13, 8365-8379, doi:10.5194/acp-13-83652013, 2013.

Raynor, G. S. and Hayes. J. V.: Differential rain and snow scavenging efficiency implied by ionic concentration differences in winter precipitation, in: Precipitation Scavenging, Dry Deposition, and Resuspension, edited by: Pruppacher, H. R., Elsevier, New York, 249-264, 1982.

Schaepman-Strub, G., Schaepman, M. E., Painter, T. H., Dangel, S., and Martonchik, J. V.: Reflectance quantities in optical remote sensing-definitions and case studies, Remote Sens. Environ., 103, 27-42, doi:10.1016/j.rse.2006.03.002, 2006.

Scott, B.: Sulfate washout ratios in winter storms, J. Appl. Meteorol., 20, 619-625, 1981.

Shindell, D. and Faluvegi, G.: Climate response to regional radiative forcing during the twentieth century, Nat. Geosci., 2, 294-300, 2009.

Stamnes, K., Tsay, S. C., Wiscombe, W., and Jayaweera, K.: Numerically stable algorithm for discrete-ordinate-method radiative-transfer in multiple-scattering and emitting layered media, Appl. Optics, 27, 2502-2509, 1988.

Wang, X., Doherty, S. J., and Huang, J. P.: Black carbon and other light-absorbing impurities in snow across 
Northern China, J. Geophys. Res.-Atmos., 118, 1471-1492, doi:10.1029/2012jd018291, 2013.

Xu, B. Q., Cao, J. J., Hansen, J., Yao, T. D., Joswia, D. R., Wang, N. L., Wu, G. J., Wang, M., Zhao, H. B., Yang, W., Liu, X. Q., and He, J. Q.: Black soot and the survival of Tibetan glaciers. Proc. Natl. Acad. Sci. USA, 106, 22114-22118, doi:10.1073/pnas.0910444106, 2009.

Yasunari, T., Tan, Q., Lau, K., Bonasoni, P., Marinoni, A., Laj, P., Ménégoz, M., Takemura, T., and Chin, M.: Estimated range of black carbon dry deposition and the related snow albedo reduction over Himalayan glaciers during dry pre-monsoon periods black carbon dry deposition, Atmos. Environ., 78, 259-267, 2013.
Zhang, Y., Suzuki, K., Kadota, T., and Ohata, T.: Sublimation from snow surface in southern mountain taiga of eastern Siberia, J. Geophys. Res., 109, D21103, doi:10.1029/2003JD003779, 2004. 